\title{
INFLUENCE OF INSTITUTIONAL FRAMEWORK ON ECONOMIC ACTIVITY OF AGRICULTURAL COOPERATIVES: LATVIA'S CASE
}

Liene Feldmane ${ }^{1}$, Mg.oec.; Andra Zvirbule ${ }^{2}$, Prof. Dr.oec.

1,2 Latvia University of Life Sciences and Technologies

\begin{abstract}
Given the important role of agricultural cooperatives in strengthening competitiveness and market power of farmers in the food chain, it is essential to understand the competitiveness of their own economic activities. The purpose of this article is to summarise the institutional base affecting agricultural cooperation to assess its impact on the economic activity. To reach the goal, the normative documents that affect the agricultural co-operation directly were gathered and studied, and certain institutional obstacles and problems affecting the cooperation of economic activity were highlighted. At the end, conclusions on the institutional framework for economic activity of agricultural cooperatives in Latvia and suggestions on the legislative changes needed to improve the competitiveness of agricultural cooperatives are offered.
\end{abstract}

Key words: agricultural cooperatives, Latvia, theory of cooperatives, legislation.

JEL code: J54, 013, P13, Q13

\section{Introduction}

Agricultural cooperative is a successful model of promoting farm competitiveness and strengthening their power in the food chain (Barrett, 2008; Soboh, 2009; FAO, 2014). There is an expectation that small farmer cooperatives will be able to address market failures and thereby achieve fair growth (Tadesse, Abate, \& Ergano, 2019). The importance of cooperatives is well shown by the Europe Union (EU) economy-there are 250,000 cooperatives in the EU, owned by 163 million citizens (one third of the EU population) and employing 5.4 million people. As to the market share, cooperatives hold substantial market shares in agriculture industry: $83 \%$ in the Netherlands, $79 \%$ in Finland, 55\% in Italy, and 50\% in France (European Commission, 2020).

There are at least three main factors that determine the success and competitiveness of cooperatives in food chains. These factors are described in a European Commission research and they are related to the position in the food supply chain, internal governance, and the institutional environment (Bijman et al., 2012). In this paper the authors focus on institutional framework which refers to the legal, political, social and cultural context in which a cooperative operates, and which may have a supporting or restrictive effect on the cooperatives.

The cooperative legislative framework in the EU Member States is of a wide range. For example, there is a very liberal cooperative legislation in Luxembourg, the Netherlands, Spain, Sweden and the United Kingdom (Bijman, Hanisch, \& van der Sangen, 2014). In contrast, cooperatives are strictly regulated in Germany, where a cooperative should undergo an annual audit to verify its compliance (Bennett, 2014; Bijman et al., 2012). The Latvian cooperative legislation framework is very similar to the one in Germany.

The purpose of this article is to summarise the institutional base affecting agricultural cooperation to assess its impact on the economic activity. To reach the goal, the research results and discussion section will give an insight into the environment of Latvian agricultural cooperatives and look at the impact of national policies on agricultural cooperation, as well analyse the national legislation and its impact on the economic activities of cooperatives. Restriction: in this article we look only at the policy and legislation's impact on the economic activity of Latvian agricultural cooperatives.

Conclusions on the influence of institutional framework on the Latvian agricultural cooperatives and suggestions for future activities including changes in legislation and researches to improve the competitiveness of agricultural cooperatives are provided in the concluding part. 
This review is based on a literature review of journal articles, book chapters and working papers, policy documents and Latvian national legislation, and secondary data. For the implementation of the research purpose and tasks will be used monographic - forming a theoretical discussion; data grouping, analysis and synthesis methods - for information collection, logical arrangement and systematization.

\section{Research results and discussion}

\section{Environment of Latvian agricultural cooperatives}

Latvia, a member of the European Union since 2004, is a small, dynamic and open economy that has successfully transformed from central planning to a market economy. Reforms have driven certain progress, albeit in agriculture it has been generally slower than in the economy as a whole (OECD, 2019). There remains a large number of small, non-commercial farms which affect the economic performance of the sector as they benefit from industry support and can contribute to black economy. The structure of commercial farms is dual: a livestock farm is generally smaller than an average EU livestock farm, while cereal farms are mostly large and export-oriented. Cereals are Latvia's main agricultural and food export commodity group (DeBoe, 2019).

This all has influence on and gives better understanding of the development of agricultural cooperatives in Latvia.

The cooperative system in Latvia has a long history with a very difficult period of transition after the Soviet Union collapsed. After the Soviet regime, the first agriculture cooperatives were established in 1992-1993 in cereals, dairy, and vegetable sectors. There were 684 agricultural services cooperative societies established during the period of 1992-2019 (The Enterprise Register of the Republic of Latvia, 2020). Nowadays 253 agriculture cooperative societies are registered (The Enterprise Register of the Republic of Latvia, 2020), but only 46 of them are recognised agricultural cooperatives.

History is an important factor influencing the institutional environment. Positive experiences of cooperative development usually have resulted in the generation of trust and increase in social capital. Development of cooperatives is influenced by the general situation in the country; a research in the EU Member States shows a clear correlation between the level of general trust as "trust in people" and cooperative performance-all New Member States have low trust and relatively little role of cooperatives (Bijman et al., 2012). In Latvia's case where the prehistory is highly antagonistic, policy makers or stakeholders should budget time for effective remedial trust building. If they cannot justify the necessary time and cost, then they should not embark on a cooperation (Ansell \& Gash, 2008).

In view of the above, on the one hand, the political environment of Latvia, which is based on common guidelines of the European Union, and, on the other, national legislation, more adapted to the specifics of Latvia, form and regulate the operation and development of Latvian agricultural cooperatives.

\section{Policy instruments for agricultural cooperatives in Latvia}

National policies highlight the role of agriculture cooperatives as an instrument for small scale farm to strengthen their competitiveness and market power in food chain. 


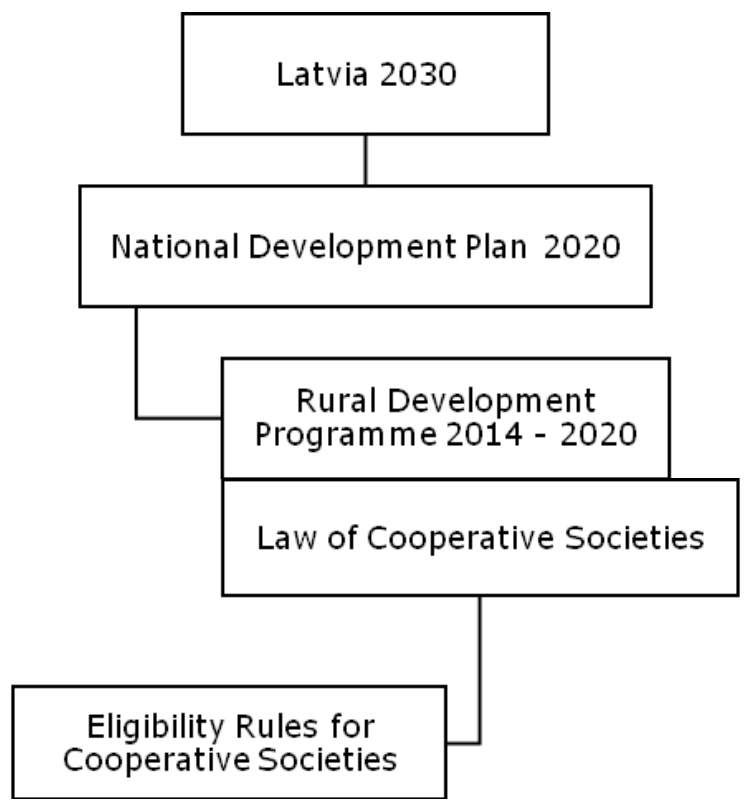

Source: created by the authors

Fig. 1. Legislative framework and domestic policy instruments of relevance to agriculture cooperatives in Latvia

According to the Sustainable Development Strategy of Latvia until 2030, a significant future challenge is to retain and develop rural areas as qualitative living and work space by fully using the diverse potential for economic development. One of solution is rural business cooperatives. The establishment of rural business cooperatives should be supported in order to ensure efficient use of production resources, improvement of sale possibilities, and more efficient representation of rural business interests under the conditions of free market (Saeima of the Republic of Latvia, 2010).

The National Development Plan 2014-2020 is hierarchically the highest national-level medium-term planning document, closely related to the Sustainable Development Strategy of Latvia until 2030 and the implementation of the EU 2020 Strategy (CCSC, 2012).

Rural Development Programme's 2014-2020 support options are mainly related to improving the processing capacity of local agricultural products and promoting cooperation (AREI, 2019). The largest numbers of agricultural cooperatives are in the dairy sector ( $29 \%$ of the total number of agricultural cooperatives) and the cereals sector (35\%), while the rest of cooperation in agricultural sectors is still an untapped potential (Ministry of Agriculture, 2019b). Various Programme activities are open for recognised agricultural cooperatives: primary producer and processing investments with separate envelopes for cooperatives; aid to producer organisations; training and innovation activities.

Primary producer investments within the planning period 2014-2020 were used by 22 cooperatives (Table 1 ). 


\section{Rural Development Programme 2014-2020 investments in agricultural cooperatives for primary treatment and processing by sectors}

\begin{tabular}{|c|c|c|c|c|c|c|}
\hline \multirow[b]{2}{*}{ Sector } & \multicolumn{3}{|c|}{$\begin{array}{l}\text { Aid for investment in agricultural holdings } \\
\text { (cooperatives envelope) }\end{array}$} & \multicolumn{3}{|c|}{ Aid for investment in processing } \\
\hline & $\begin{array}{l}\text { No. of cooperatives } \\
\text { (total no. of } \\
\text { recognized } \\
\text { cooperatives) }\end{array}$ & $\begin{array}{l}\text { No. of } \\
\text { projects }\end{array}$ & $\begin{array}{c}\text { Amount of } \\
\text { public } \\
\text { funding, EUR }\end{array}$ & $\begin{array}{l}\text { No. of } \\
\text { cooperatives }\end{array}$ & $\begin{array}{l}\text { No. of } \\
\text { projects }\end{array}$ & $\begin{array}{c}\text { Amount of } \\
\text { public } \\
\text { funding, } \\
\text { EUR }\end{array}$ \\
\hline Cereals & $14(15)$ & 65 & $20,013,438$ & 0 & 0 & 0 \\
\hline Dairy & $6(24)$ & 9 & 382,618 & 2 & 5 & 308,742 \\
\hline $\begin{array}{l}\text { Vegetables } \\
\text { and fruits }\end{array}$ & $2(5)$ & 4 & 212,894 & 1 & 1 & $5,000,000$ \\
\hline Total & $22(46)$ & 78 & $20,608,950$ & 3 & 6 & $5,308,742$ \\
\hline
\end{tabular}

Source: created by the authors using the data of Paying Agency and Latvian Association of Agricultural Cooperatives (Paying Agency, 2020; LLKA, 2020)

Cereals cooperatives have made the largest investments in primary processing, accounting for $97 \%$ of the available funding, and the dairy cooperatives for $2.7 \%$ of the available funding (Paying Agency, 2020). Cereals and milk are the main agricultural export sector (Ministry of Agriculture, 2019). The industry weakness lies in the fact that the main export goods are raw products with no added value. In view of the cooperative investment attraction rate, one can assess the trends in sectoral fundraising ability and competitiveness of cooperatives, which generally is seen as weak.

\section{Legislative framework of agriculture cooperatives in Latvia}

A new law on cooperative societies was adopted in 2018. Comparing with the previous version, this is an umbrella law of all kind of cooperative societies. The aim of Law is to create favourable regulatory conditions for cooperatives-voluntary associations of individuals whose purpose is to promote effective implementation of members' common economic interests (Saeima of the Republic of Latvia, 2018). As mentioned above, in order to evaluate functioning of agricultural cooperatives in the interests of members, a procedure was developed which, when the new law came into force, was even more important for the identification of agricultural cooperatives. The procedure for the recognition of cooperative societies of agricultural services was introduced in accordance with the Cabinet Regulations "Eligibility Rules for Cooperative Societies" (Cabinet of Ministers of the Republic of Latvia, 2019) in 2004. Responsibility for this procedure lies with the Ministry of Agriculture who has delegated this activity to the Latvian Association of Agriculture Cooperatives since 2010. The status of a recognised cooperative society of agricultural services is received by around 50 cooperatives every year (LLKA, 2020).

If the cooperative has been recognised, it is a kind of guarantee to the farmer that the cooperative can be trusted. In addition, obtaining the recognition status gives you the opportunity to receive national and European aid for cooperatives, as well as other statutory benefits. Every year recognition commission evaluates and grants the recognition status for one year. Idea of cooperative recognition came from Germany where a typical element in the governance of cooperatives is that every cooperative must be member of an auditing association. The same requirement is in Austria too. (Bijman et al., 2012).

Authors' analysis on the impact of innovations and key criteria on cooperative society's law and eligibility rules on the economic performance of agricultural cooperatives is presented in Table 2. 
National legal framework and main actions influencing the economic activity of agricultural cooperatives

\begin{tabular}{|c|c|c|c|}
\hline No. & Subject & $\begin{array}{l}\text { Law of cooperative societies } \\
\text { adopted } 12 \text { April } 2018\end{array}$ & $\begin{array}{c}\text { Eligibility Rules for Cooperative } \\
\text { Societies, Regulations No. 357, adopted } \\
16 \text { July } 2019\end{array}$ \\
\hline 1. & $\begin{array}{l}\text { Purpose of } \\
\text { cooperative }\end{array}$ & $\begin{array}{l}\text { This Law is to create favourable } \\
\text { regulatory conditions for } \\
\text { cooperatives-voluntary associations } \\
\text { of individuals whose purpose is to } \\
\text { promote effective implementation of } \\
\text { members' collective economic } \\
\text { interests. }\end{array}$ & $\begin{array}{l}\text { Recognition status shall be granted to a } \\
\text { company if it provides services to its } \\
\text { members but does not engage in production } \\
\text { (except for the processing or treatment of } \\
\text { the products produced by the members) and } \\
\text { meets the criteria of these Regulations, } \\
\text { depending on its type of activity. }\end{array}$ \\
\hline 2. & Turnover & & $\begin{array}{l}\text { Turnover includes the goods sold and } \\
\text { services provided, which are necessary for } \\
\text { production. } \\
\text { The criteria include: } \\
\text { The cooperative sells agricultural produce } \\
\text { produced on its member's farm or purchased } \\
\text { from its member, which is another } \\
\text { cooperative. } \\
\text { Turnover between cooperatives and } \\
\text { members represents at least } 75 \% \text { of } \\
\text { turnover, with a turnover of at least } \\
5 \text { members it should be } 80 \% \text {. } \\
\text { Turnover with one member does not exceed } \\
40 \% \text { of the cooperative's total turnover. } \\
\text { Cooperative has a turnover with minimum } 10 \\
\text { members, but for a cooperative which } \\
\text { operates in the fruit and vegetables or } \\
\text { poultry industry or provides agricultural } \\
\text { technical services, or whose members are } \\
\text { only other cooperatives - with at least five } \\
\text { members. } \\
\text { Minimum turnover between cooperatives and } \\
\text { members is } 20,000 \text { euros in the reporting } \\
\text { year. }\end{array}$ \\
\hline 3. & $\begin{array}{l}\text { Profit } \\
\text { payment } \\
\text { procedure }\end{array}$ & $\begin{array}{l}\text { The profits of the cooperative may } \\
\text { be paid out: } \\
\text { To members determined in } \\
\text { proportion to the amount of } \\
\text { cooperative services it uses. } \\
\text { Articles of association may provide } \\
\text { that the whole profit to be disbursed } \\
\text { to a member or its part shall be } \\
\text { determined in proportion to the } \\
\text { number of shares paid by the } \\
\text { member. }\end{array}$ & $\begin{array}{l}\text { The regulation does not provide patronage } \\
\text { member's participation in the cooperative. }\end{array}$ \\
\hline
\end{tabular}

Source: created by the authors

\subsection{Purpose of cooperatives}

Cooperative action is only based on economic efficiency. The annotation of the Law explains that the essence of a cooperative society is the cooperation of its members for the realisation of common economic and other interests, although only the economic interests are covered by the Law. Currently, the Law only defines the economic direction of a cooperative and does not distinguish a cooperative from any other form of business. However, as several scientists have pointed out, a cooperative is more than just a business. For example, V. James Rhodes states in his article that "the cooperative generally is not simply an unconstrained money maker as may be an investor owned firm" (Rhodes, 1983). Members may experience not only an economic commitment but also an affective commitment to the cooperative (Jussila, Byrne, \& Tuominen, 2012). The affective commitment is based on an emotional attachment to the cooperative (Jussila, Goel, \& Tuominen, 2012; Ollila, Nilsson, \& Hess, 2014), which may be demonstrated as support to the cooperative 
mission. Generally, the cooperative mission is often defined in terms of marketing of pooled resources. Affective commitment has also been described as commitment to collective action (Borgen, 2001; Cechin, Bijman, Pascucci, \& Omta, 2013; Grashuis \& Cook, 2019). In other words, cooperative members who are as well owners and users are not only interested in making profits as investors, but they also have an essential social component to the cooperative, it is a way of life (Torgerson \& Reynolds, 1999).That means when the non-economic factors are strong, members may patronise the cooperative even if the price or service of the cooperative is not as good as the ones of alternative firms (Jussila, Goel, et al., 2012).

The European Commission and the International Cooperative Alliance define cooperative as people-centred enterprise jointly owned, controlled and run by and for their members to realise their common economic, social and cultural needs and aspirations (European Commission, 2020, International Cooperative Alliance, 2020).

In the light of other authors and Internal Cooperative Alliance (ICA) and the EU cooperative principles of action, which also include cooperative social functions, the Latvian institutional framework needs to be supplemented with the basic principles of cooperation, including social components. Cooperative's social factors are important for its economic activity, and these factors are the knowledge and level of understanding, ownership and confidence indicators of members.

Ignoring this social factor in the Cooperative Societies Law of Latvia, according to any legislator, equates agricultural cooperatives with an investor enterprise, thus having a negative impact on the competitiveness of cooperatives. For example, the provisions of the Enterprise Income Tax Law (Saeima of the Republic of Latvia, 2017) regarding representation expenses and expenses for sustainable activities of staff, training and consolidation of cooperative members and employees are treated as representation expenses and are subject to income tax. In other words, representation is regarded as one of the basic functions of a cooperative, which gives a negative impact on the economic performance of cooperatives as a whole.

\subsection{Turnover}

On one hand, cooperatives can be formed to meet many different needs and aspirations, and there are many different ways in which cooperatives can do so while respecting the principles and values of collaboration. The form of the cooperative will largely depend on what problem the cooperative is primarily trying to solve-lack of access to certain types of goods, low price or poor market access of a certain product etc. Almost any cooperative can have more than one feature. Farmers more often are members of producers' cooperative. There are many ways in which these groups can cooperate: they can buy farm inputs, equipment and insurance, hire managers and sales staff to market and advertise together, or use storage or processing equipment or distribution network. These are also sometimes known as marketing cooperatives in which each farmer maintains a fairly independent path to market, but shares the brand (Austin Cooperative Business Association, 2014). In the agricultural sector we now can see also hybrid forms of cooperatives. These hybrid forms have two aspects: firstly, in adopting a multi-stakeholder governance structure and, secondly, in terms of using multiple resources (Spear Roger, 2011; Chaddad, 2012).

On the other hand, the criterion stipulated in the Regulations-a cooperative sells agricultural produce produced on its member's farm-promotes the cooperative that sells the produce produced by its members, but it limits the opportunities for other forms of agricultural cooperatives, such as agricultural cooperatives that provide members with inputs, feed, breeding material. 
However, it should be noted that cooperatives can combine different forms of activity. The current regulatory framework restricts strengthening of competitiveness of agricultural cooperatives in this way.

\subsection{Profit payment procedure}

The articles of association may consolidate the two types of profit sharing. For example, if a cooperative wants to attract an investor-type member, it may stipulate in its articles of association that a proportion of the cooperative's profits shall be distributed in proportion to the amount of its contribution. The Regulations, however, do not provide for the participation of a patronage member in the cooperative and also the issue of creating hybrid cooperatives is missing from the Law. In the EU Member States that allow both approaches, attracting foreign investors is still at an early stage (Bijman et al., 2012).

On one side, this kind of regulation helps policy makers to influence agriculture cooperatives and guide them to directions that are important for policies-environmental, sustainable, "Green Deal" issues (European Commission, 2019b). Scholars also stress the development of a fuller understanding of the role of cooperatives specifically, and collective action in the economy in general is likely to become more important given the emergence of a new set of issues facing the world in the twenty-first century. Food security is one of these issues, while other are health care, carbon sequestration and trading, environmental conservation and protection, alternative energy sources, and alternative food sources (e.g., organic, local). Given the importance of externalities and nonmarket impacts (e.g., impact on the local community) in all these issues, a collective response of some sort to these issues would seem to be necessary (Fulton \& Giannakas, 2013). States and markets are not separate, and must, therefore, come together and be reinforced by citizen action, especially for meeting global public objectives such as sustainable development (Scoones, 2016).

On the other side, Regulations No. 357 of 2019 (Cabinet of Ministers of the Republic of Latvia, 2019) restrict the activities of agriculture cooperatives by recognising and considering only direct agricultural services to members such as accounting, financial, legal, and project preparation services which are appropriate and enhance the competitiveness of the cooperative. In order to support the development of Latvian agricultural cooperatives, it is necessary to modernise these regulations, with the emphasis on the cooperatives' operational objective-to strengthen the competitiveness of agricultural holdings in food chain (European Commission, 2019a), and evaluate all the services provided to the cooperative members.

\section{Conclusions, proposals, recommendations}

1) Since Latvia is small and open economy, to overcome the communist legacy there is a need to invest resources and time in building trust and in the understanding of the foundations of cooperation. This should be taken into account when designing policies that affect the competitiveness of the agricultural sector as a whole.

2) There are financial instruments and political support available to develop and strengthen agricultural cooperation for added value products, to increase income for farmers and make them stronger in food chain, but:

- 22 out of 46 recognised cooperatives used the European Agricultural Fund for Rural Development support; $97 \%$ of funding for investments in first processing received cereals sector, and only $2.7 \%$ of the amount were allocated to the second largest agricultural export sector-dairy sector;

- the amount of members in agricultural cooperatives has not risen in a ten year period. 
- This indicates that cooperatives do not have the financial resources and / or strategies to develop their activities-patronage of members is weak. There are instruments which could be used for strengthening the competitiveness of agricultural cooperatives, but there is still mistrust and lack of long-term planning between farmers.

3) The new Cooperative Societies Law is progressive and, overall, promotes the competitiveness of cooperatives. However, it is necessary to clarify the definition of cooperative in the regulatory framework to include the social component highlighting the distinction between cooperative and investor enterprise.

4) Also the Regulations "Eligibility Rules for Cooperative Societies" should be revised to expand the range of services provided by the cooperative to its members. This would facilitate expansion of cooperatives and more meaningful participation of their members. Cooperatives should be stimulated to offer more products and services to members.

5) Taking into account the influence of history and the scientific research on the importance of trust as an indicator of influence on the development of the cooperative, research on the internal operating environment of Latvian agricultural cooperatives and its influencing factors is necessary.

\section{Bibliography}

1. Ansell, C., \& Gash, A. (2008). Collaborative Governance in Theory and Practice. Journal of Public Administration Research and Theory, 18(4), 543-571. Retrieved from https://doi.org/10.1093/jopart/mum032

2. AREI. (2019). Annual Program Report Latvia - Rural Development Program, Year 2018. Retrieved March 11, 2020, from https://www.zm.gov.Iv/public/ck/files/LAP_gada_zinojums_2018.pdf

3. Austin Cooperative Business Association. (2014). Types of Cooperatives. Website Austin Cooperative Business Association, 1-5. Retrieved from http://www.acba.coop/types_of_cooperatives

4. Barrett, C. B. (2008). Smallholder Market Participation: Concepts and Evidence from Eastern and Southern Africa. Food Policy, 33(4), 299-317. Retrieved from https://doi.org/10.1016/j.foodpol.2007.10.005

5. Bennett, D. (2014). Eastern German Cooperative Farming: On the Cusp of a New Generation. German Politics and Society, 32(4), 56-68. Retrieved from https://doi.org/10.3167/gps.2014.320404

6. Bijman, J., Hanisch, M., \& van der Sangen, G. (2014). Shifting Control? The Changes of Internal Governance in Agricultural Cooperatives in the EU. Annals of Public and Cooperative Economics, 85(4), 641-661. Retrieved from https://doi.org/10.1111/apce.12055

7. Bijman, J., Iliopoulos, C., Poppe, K. J., Gijselinckx, C., Hagedorn, K., Hanisch Markus, ... Ger van der Sangen. (2012). Support for Farmers. In Final Report. Support for farmers' Cooperatives - Study. Retrieved from https://op.europa.eu/en/publication-detail/-/publication/a2929ebd-e7d0-4ccf-a744-3bf5a4caeffd/languageen/format-PDF/source-search

8. Borgen, S. O. (2001). Identification as a Trust Generating Mechanism in Cooperatives. Annals of Public and Cooperative Economics, 72(2), 209-228. Retrieved from onlinelibrary.wiley.com/doi/pdf/10.1111/14678292.00165?casa_token=RsdaWtmF8WsAAAAA:Hzzjk2_FMeVBb_5KRRoeqIUKMxqsNJpCyWTS44JgqWQGe8X 9RkaEngNZHwLUVaXmsJut84OpvBMNew

9. Cabinet of Ministers of the Republic of Latvia. (2019). Eligibility Rules for Cooperative Societies (Kooperativo sabiedribu atbilstibas noteikumi). Retrieved March 11, 2020, from https://likumi.lv/ta/id/308382kooperativo-sabiedribu-atbilstibas-noteikumi

10.CCSC. (2012). National Development Plan of Latvia for 2014-2020. Retrieved from Cross-Sectoral Coordination Centre(CCSC) website: https://www.pkc.gov.lv/sites/default/files/inline-files/NDP2020 English Final___ 1.pdf

11. Cechin, A., Bijman, J., Pascucci, S., \& Omta, O. (2013). Decomposing the Member Relationship in Agricultural Cooperatives: Implications for Commitment. Agribusiness, 29(1), 39-61.

12. Chaddad, F. (2012). Advancing the Theory of the Cooperative Organization: The Cooperative as a True Hybrid. Annals of Public and Cooperative Economics, 83(4), 445-461. Retrieved from https://doi.org/10.1111/j.14678292.2012.00472.x

13. DeBoe, G. (2019). Impacts of Agricultural Policies on Productivity and Sustainability Performance in Agriculture: A Literature Review. (141), 79. Retrieved from http://www.oecd.org/tad/agriculturalpolicies/innovation-food-agriculture.htm.

14. European Commission. (2019a). The Common Agricultural Policy. Retrieved from https://ec.europa.eu/info/sites/info/files/food-farming-fisheries/key_policies/documents/cap-separatingfacts-from-fiction_en.pdf

15. European Commission. (2019b). The European Green Deal. Retrieved from https://ec.europa.eu/info/publications/communication-european-green-deal_en 
16. European Commission. (2020). Cooperatives. Retrieved March 5, 2020, from https://ec.europa.eu/growth/sectors/social-economy/cooperatives_en

17.FAO. (2014). The State of Food and Agriculture. Innovation in Family Farming. In Food and Agriculture Organization of the United Nations. Retrieved from http://www.fao.org/3/a-i4040e.pdf

18. Fulton, M., \& Giannakas, K. (2013). The Future of Agricultural Cooperatives. In Annual Review of Resource Economics (Vol. 5). Retrieved from https://doi.org/10.1146/annurev-resource-091912-151928

19. Grashuis, J., \& Cook, M. L. (2019). A Structural Equation Model of Cooperative Member Satisfaction and Longterm Commitment. International Food and Agribusiness Management Review, 22(2), 247-263. Retrieved from https://doi.org/10.22434/IFAMR2018.0101

20. International Cooperative Alliance. (2020). What is a Cooperative? Retrieved March 11, 2020, from https://www.ica.coop/en/cooperatives/what-is-a-cooperative

21. Jussila, I., Byrne, N., \& Tuominen, H. (2012). Affective Commitment in Co-operative Organizations: What Makes Members Want to Stay? International Business Research, 5(10), 1-10. Retrieved from https://doi.org/10.5539/ibr.v5n10p1

22. Jussila, I., Goel, S., \& Tuominen, H. (2012). Member Commitment in Co-operatives: The Utilitarian Approach. Business and Management Research, 1(3), 9-16. Retrieved from https://doi.org/10.5430/bmr.v1n3p9

23. LLKA. (2020). Latvian Association of Agricultural Cooperatives. Retrieved March 5, 2020, from http://www.llka.Iv/atbilstibas-Ipks/

24. Saeima of the Republic of Latvia. (2017). Enterprise Income Tax Law (Uznemumu ienakuma nodokla likums). Retrieved March 11, 2020, from https://likumi.lv/ta/id/292700-uznemumu-ienakuma-nodokla-likums

25. Saeima of the Republic of Latvia. (2018). Co-operative Societies Law (Kooperativo sabiedribu likums). Retrieved March 11, 2020, from https://likumi.Iv/ta/id/298656-kooperativo-sabiedribu-likums

26. Ministry of Agriculture. (2019a). Foreign Trade. Retrieved March 5, 2020, from Foreign Trade in Food, Agricultural and Fishery Products in the Half of 2019 website: https://www.zm.gov.lv/zemkopibasministrija/statiskas-lapas/partikas-lauksaimniecibas-un-zivsaimniecibas-produktu-arejastirdzniec?id=1577\# jump

27. Ministry of Agriculture. (2019b). Latvia -Rural Development Programme 2014 - 2020. Retrieved March 11, 2020, from https://www.zm.gov.Iv/public/files/CMS_Static_Page_Doc/00/00/01/50/34/Programme_7.pdf

28. OECD. (2019). Inovacijas, lauksaimniecibas produktivitate un ilgtspejiba Latvija. In Inovacijas, lauksaimniecibas produktivitate un ilgtspejiba Latvija. Retrieved from https://doi.org/10.1787/279bde8c-lv

29. Ollila, P., Nilsson, J., \& Hess, S. (2014). Farmers' Reactions to the Internationalisation of Cooperatives. Agricultural and Food Science, 23(4), 291-306. Retrieved from https://doi.org/10.23986/afsci.45222

30. Paying Agency. (2020). RDP 2014 - 2020. Retrieved March 5, 2020, from Information of Investment Projects website: http://www.lad.gov.Iv/Iv/atbalsta-veidi/projekti-un-investicijas/operativa-informacija/

31. Rhodes, V. J. (1983). The Large Agricultural Cooperative As a Competitor. American Journal of Agricultural Economics, 65(5), 1090-1095. Retrieved from https://doi.org/10.2307/1240426

32. Saeima of the Republic of Latvia. (2010). Sustainable Development Strategy of Latvia Until 2030. Retrieved from https://www.pkc.gov.Iv/sites/default/files/inline-files/LIAS_2030_en_0.pdf

33. Scoones, I. (2016). The Politics of Sustainability and Development. Annual Review of Environment and Resources, 41(1), 293-319. Retrieved from https://doi.org/10.1146/annurev-environ-110615-090039

34. Soboh, R. (2009). Econometric Analysis of the Performance of Cooperatives and Investor Owned Firms in the European Dairy Industry. Retrieved from http://library.wur.nl/WebQuery/wda/lang/1924922

35. Spear Roger. (2011). Formes Cooperatives Hybrides. Recma: Revue Internationale de I"economie Sociale, 320. Retrieved from http://recma.org/node/1281

36. Tadesse, G., Abate, G. T., \& Ergano, K. (2019). The Boundary of Smallholder Producers' Cooperatives: A Conceptual and Empirical Analysis. Journal of Agricultural Economics, 70(2), 529-549. Retrieved from https://doi.org/10.1111/1477-9552.12310

37. The Enterprise Register of the Republic of Latvia. (2020). Basic data on entities registered. Retrieved March 11, 2020, from https://www.ur.gov.Iv/en/specialized-information/open-data/

38. Torgerson, R. E., \& Reynolds, B. J. (1999). Evolution of Cooperative Thought, Theory, and Purpose. Journal of Cooperatives, 13, 1-20. 